\title{
Inhibitory Effects of Ginsenoside Re Isolated from Ginseng Berry on Histamine and Cytokine Release in Human Mast Cells and Human Alveolar Epithelial Cells
}

\author{
Hye Min Bae ${ }^{1}$, Ok Sun Cho ${ }^{1}$, Shin Jung Kim², Byung Ok $\mathrm{Im}^{3}$, Soon Hyun $\mathrm{Cho}^{4}$, Sena Lee, \\ Myung-Gyou Kim ${ }^{5}$, Kyung Tack Kim ${ }^{6}$, Kang Hyun Leem ${ }^{5 *}$, and Sung Kwon Ko ${ }^{1 *}$ \\ ${ }^{1}$ Department of Oriental Medical Food \& Nutrition, Semyung University, Jecheon 390-711, Korea \\ ${ }^{2}$ College of Pharmacy, Sookmyung Women's University, Seoul 140-742, Korea \\ ${ }^{3}$ Department of Natural Medicine Resources, Semyung University, Jecheon 390-711, Korea \\ ${ }^{4}$ Department of Pharmacy \& Food, Daewon University College, Jecheon 390-702, Korea \\ ${ }^{5}$ College of Oriental Medicine, Semyung University, Jecheon 390-711, Korea \\ ${ }^{6}$ Processing Technology Research Group, Korea Food Research Institute, Seongnam 463-746, Korea
}

The berry of Panax ginseng significantly inhibited the histamine releases at the concentration of $30 \mu \mathrm{g} / \mathrm{mL}(p<0.05)$ and 10 $\mu \mathrm{g} / \mathrm{mL}(p<0.01)$. The ginsenoside Re from ginseng berry was found out to have a potent effect in the experiment of histamin and cytokine release.

Keywords: Panax ginseng, Ginseng berry, Ginsenoside Re, Histamine, Cytokine

The root of ginseng (Panax ginseng Meyer) has been traditionally used for medicine and food stuff. The primary physiologically active substances of ginseng are ginsenosides, polyacetylenes, ginseng proteins, polysaccharides, and phenolic compounds, etc. [1-4]. Ginsenosides, in particular, have been noticed as the principal effective component of ginseng showing various biochemical and pharmacological efficacies. A number of researchers have studied the components of ginseng since the late 1960s starting with the research of Shibata $[5,6]$, whose research group identified the chemical structures of ginsenoside. The physiological activities of these ginsenosides have been reported to show anti-cancer effects [7], anti-diabetic effects [8], protection of the central nervous system [9], anti-arteriosclerotic and hypertensive effects $[10,11]$, improvement of liver function and clearing of hangovers [12], anti-fatigue and anti-stress effects $[13,14]$, anti-oxidative qualities [15], anti-inflammatory effects [16], promotion of protein synthesis [17], and strengthening the immune system [18]. To examine and identify the efficacies of ginsenosides as mentioned above, a number of biochemical and pharmacological studies have been conducted. Many researchers are still eagerly trying to discover new efficacies of ginsenoside.

Until recently, most of the ginseng research has focused on the components of the ginseng root [19-21]. However, in addition to the ginseng root, the components of the ginseng berry and their pharmacological activities (cc) This is an Open Access article distributed under the terms of the Creative Commons Attribution Non-Commercial License (http://creativecommons.org/licenses/by-nc/3.0/) which permits unrestricted non-commercial use, distribution, and reproduction in any medium, provided the original work is properly cited.
Received 04 Jul. 2012, Revised 24 Aug. 2012, Accepted 24 Aug. 2012

*Corresponding authors

E-mail: 1kh@semyung.ac.kr

Tel: +82-43-649-1341, Fax: +82-43-649-1341

E-mail: skko@semyung.ac.kr

Tel: +82-43-649-1433, Fax: +82-43-649-1759 
have also been reported such as: anti-diabetic [22-24], anti-cancer [25,26], anti-oxidant, anti-aging [27-30], and anti-stress [31], etc. As the interest in the ginseng berry has increased recently, many studies have been carried out. However, the research on the anti-allergic effects of ginseng berries has not been performed. Therefore, the present study investigated the influence on anti-histamine releasing activity of the ginseng berry (except the seeds from the berry), and the active components were purified and identified as ginsenoside Re.

The berry of a 4-year cultivated ginseng plant was collected at Kimjae (cultivated by Gil Kim) in Korea on July 14, 2007. Images of the ginseng berry are shown in Fig. 1. These specimens were stored at the Oriental Medical Food Research Laboratory of Semyung University. Dried ginseng berries $(5 \mathrm{~kg})$ were ground to powder and extracted twice with $1 \mathrm{~L}$ of $95 \%$ ethyl alcohol for $2 \mathrm{~h}$ in a water bath $\left(60^{\circ} \mathrm{C}\right)$. The extracts were concentrated by a vacuum evaporator (Eyela Co., Tokyo, Japan).

In order to determine the effects of ginseng berries on histamine release, the human leukemic mast cells (HMC1) were used. The HMC-1 was cultured in Iscove's modified Dulbecco's media containing $10 \%$ bovine serum albumin, $2 \mathrm{mM}$ L-glutamine, $100 \mathrm{IU} / \mathrm{mL}$ penicillin, and $50 \mu \mathrm{g} / \mathrm{mL}$ streptomycin. The cells were cultured at $37^{\circ} \mathrm{C}$ in a $5 \% \mathrm{CO}_{2}$ with $95 \%$ humidity and were passaged every 2 to $3 \mathrm{~d}$. HMC- 1 was subcultured in a 24 well plate and stabilized for $24 \mathrm{~h}$. They were divided into six groups; vehicle-treated blank, control, 30, 10, 3, and $1 \mu \mathrm{g} / \mathrm{mL}$ ginseng berry-treated groups. After $30 \mathrm{~min}$, every well except the blank group was treated with compound 48/80 $(1 \mathrm{mg} / \mathrm{mL})$. The same volume of distilled water was treated in the blank wells. After incubation for
15 min, histamine levels of the supernatants were measured. Specific processes of histamine assay were as follows. $\mathrm{NaOH}(1 \mathrm{M})$ and o-phthaldialdehyde $(1 \mathrm{mg} / \mathrm{mL}$ in $\mathrm{EtOH}$ ) were added to all wells. After 4 min, fluorescent measurements were made using a Synergy HT (Bio-Tek Instruments Inc., Winooski, VT, USA).

In order to determine release of inflammatory cytokines on human alveolar basal epithelial cells (A549) by treatment with ginseng berry, cytokines were measured using the RayBio Human Cytokine Antibody Array kit (RayBiotech, Norcross, GA, USA) according to the protocol of the manufacturer. In brief, A549 cells was seeded into a 6 well plate at a density of $2 \times 10^{5}$ cells/well and incubated at $37^{\circ} \mathrm{C}$ for $24 \mathrm{~h}$. After then, ginseng berry or ginsenoside Re with lipopolysaccharide (LPS) was treated and incubated for $24 \mathrm{~h}$, and the cellular proteins were extracted from the cells using a protein extract buffer. Array membranes were incubated with blocking buffer at room temperature for 30 min to block membranes and blocking buffer was decanted and $1 \mathrm{~mL}$ of each protein was added each membrane. After $2 \mathrm{~h}$, each protein was decanted and membranes were washed 5 times with wash buffer I and II. And then, biotin-conjugated anticytokines were diluted with blocking buffer and were added and incubated to each membrane for $2 \mathrm{~h}$. Membranes were washed 5 times and incubated with 1,000 fold diluted horseradish peroxidase-conjugated streptavidin for $2 \mathrm{~h}$ and then washed 5 times. Enhanced chemiluminescence buffer was added to each membrane and the signals were detected using Fusion chemiluminescence imaging system and analyzed by Bio1D software (Vilber Lourmat, Marne La Vallee, France).

The results were expressed as mean $\pm \mathrm{SD}$. The data
A

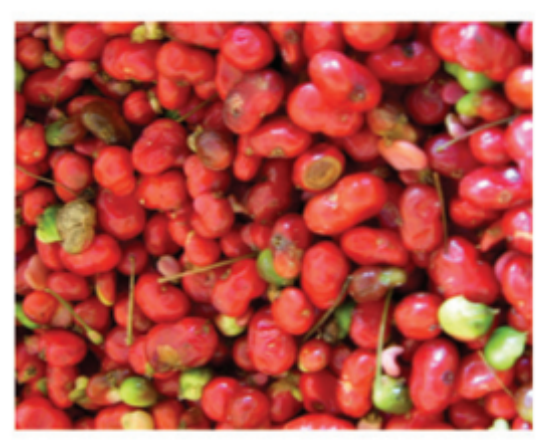

B

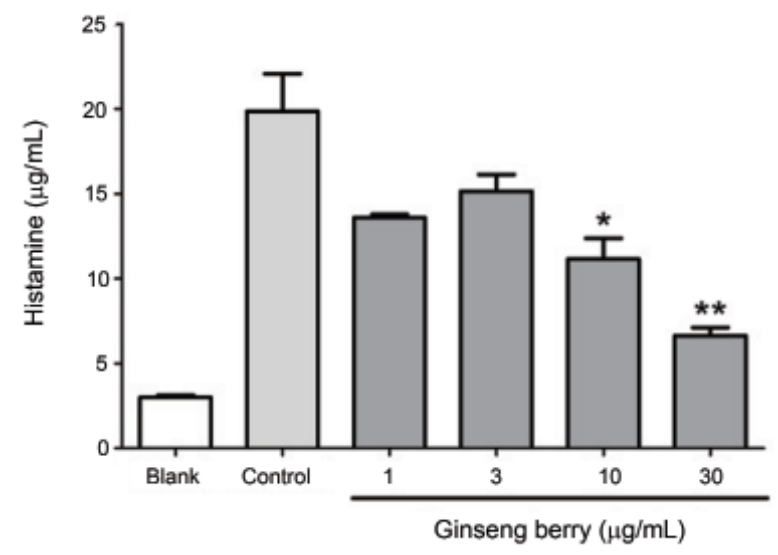

Fig. 1. Photograph of ginseng berry (A) and histamine content of cultured supernatants of human mast cells (B). Blank group was not incubated with compound $48 / 80$, and other experimental groups were incubated with compound $48 / 80\left({ }^{*} p<0.05,{ }^{* *} p<0.01\right.$ vs. control). 

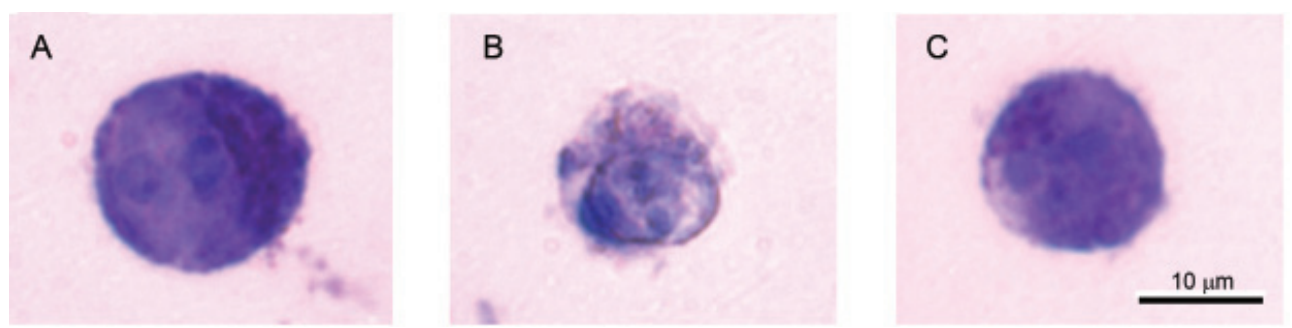

Fig. 2. Microphotographs of degranulation in human mast cells. (A) An unstimulated mast cell. (B) The cell has been activated to secrete its stored histamine by compound $48 / 80$. (C) The extracts of ginseng berry $(30 \mu \mathrm{g} / \mathrm{mL})$ prevented the histamine secretion induced by compound $48 / 80$.

A

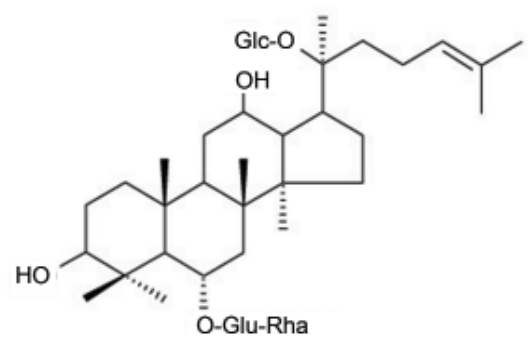

Compound I : 20(S)-ginsenoside-Re Gic : $\beta$-D-giucopyranosyl Rha : $\alpha$-L-rhamnopyranosyl
B

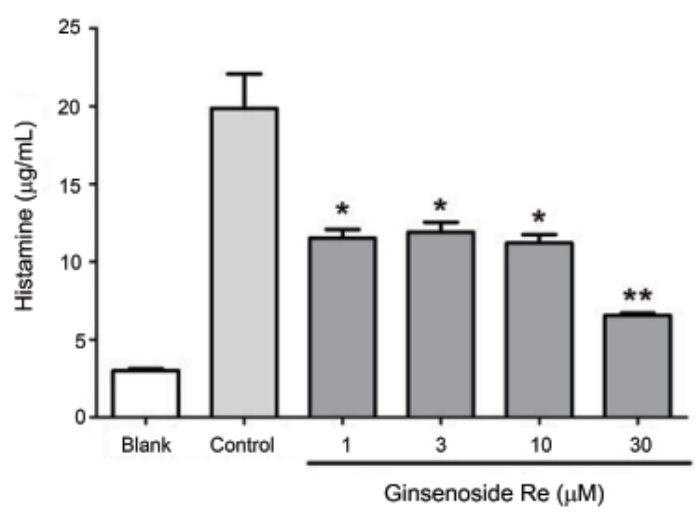

Fig. 3. Chemical structures of compound $I(A)$ and histamine content of cultured supernatants of human mast cells (B). Blank group was not incubated with compound $48 / 80$, however, other experimental groups were incubated with compound $48 / 80\left({ }^{*} p<0.05\right.$, ${ }^{* *} p<0.01$ vs. control).

was analyzed by one-way ANOVA, followed by Tukey's post-hoc analysis using SPSS (SPSS Inc., Chicago, IL, USA). Differences were considered significant at $p<0.05$.

Toluidine blue ( $\mathrm{pH}$ 5.0) staining was performed to observe the cytotoxicity of tested materials, because cell death including apoptosis and necrosis could increase histamine concentration. The degranulations in HMC-1 stimulated with compound $48 / 80$ were observed morphologically after $0.05 \%$ toluidine staining (Fig. 2B) whereas not stimulated HMC-1 showed the darker staining of granules in cytoplasm (Fig. 2A). The extract of ginseng berry prevented the degranulation of HMC-1 (Fig. 2C).

As shown in Fig. 1B, the histamine secretion in blank group was $3.0 \pm 0.2 \mu \mathrm{g} / \mathrm{mL}$ and it was increased by compound $48 / 80$ treatment to $19.9 \pm 3.1 \mu \mathrm{g} / \mathrm{mL}$ in the control group. The compound 48/80-induced histamine secretions were reduced by the ginseng berry treatment in a dose-dependent manner. The histamine secretions at the concentrations of $30,1,3,10$, and $30 \mu \mathrm{g} / \mathrm{mL}$ were $13.6 \pm 0.3,15.2 \pm 1.4,11.1 \pm 1.7$, and $6.6 \pm 0.7 \mu \mathrm{g} / \mathrm{mL}$, respectively (Fig. 1B), with the statistical significances at $30 \mu \mathrm{g} / \mathrm{mL}(p<0.01)$ and $10 \mu \mathrm{g} / \mathrm{mL}(p<0.05)$.
Ninety-five percent EtOH extract of ginseng berry $(1,080 \mathrm{~g})$ was dissolved in distilled water and it was partitioned 10 times with diethyl ether resulting in $45 \mathrm{~g}$ of diethyl ether fraction and $998 \mathrm{~g}$ of water fraction. The water fraction (998 g) was suspended in distilled water and was adsorbed in a Diaion HP-20 (Mitsubishi Chemical Co., Tokyo, Japan) ion exchange resin column. Thirty percent $\mathrm{MeOH}$ fraction, $50 \% \mathrm{MeOH}$ fraction, $70 \%$ $\mathrm{MeOH}$ fraction, and $100 \% \mathrm{MeOH}$ fraction were eluted in the order named. The $30 \% \mathrm{MeOH}$ fraction (10 g) was then subjected to an octadecyl silane (12 nm S-75 um; YMC ODS-A, YMC Co., Kyoto, Japan) gel column by gradient elution with $30 \%$ to $100 \% \mathrm{MeOH}$ and resulted in 4 subfractions (F1-F4). The F3 subfraction (1.2 g) that exerted the highest inhibitory effect on histamine release was rechromatographed on silica gel column with a mixture of the solvents $\left(\mathrm{CHCl}_{3}: \mathrm{MeOH}: \mathrm{H}_{2} \mathrm{O}=70: 30: 4 \mathrm{v} /\right.$ v) and $0.6 \mathrm{~g}$ of compound I was isolated and identified as ginsenoside Re by the spectroscopic methods of ${ }^{1} \mathrm{H}$ NMR, ${ }^{13} \mathrm{C}-\mathrm{NMR}$, and FAB-MS (Fig. 3A). The isolated ginsenoside Re treatment at concentrations of $1,3,10$, and $30 \mu \mathrm{M}$ significantly reduced histamine secretion 

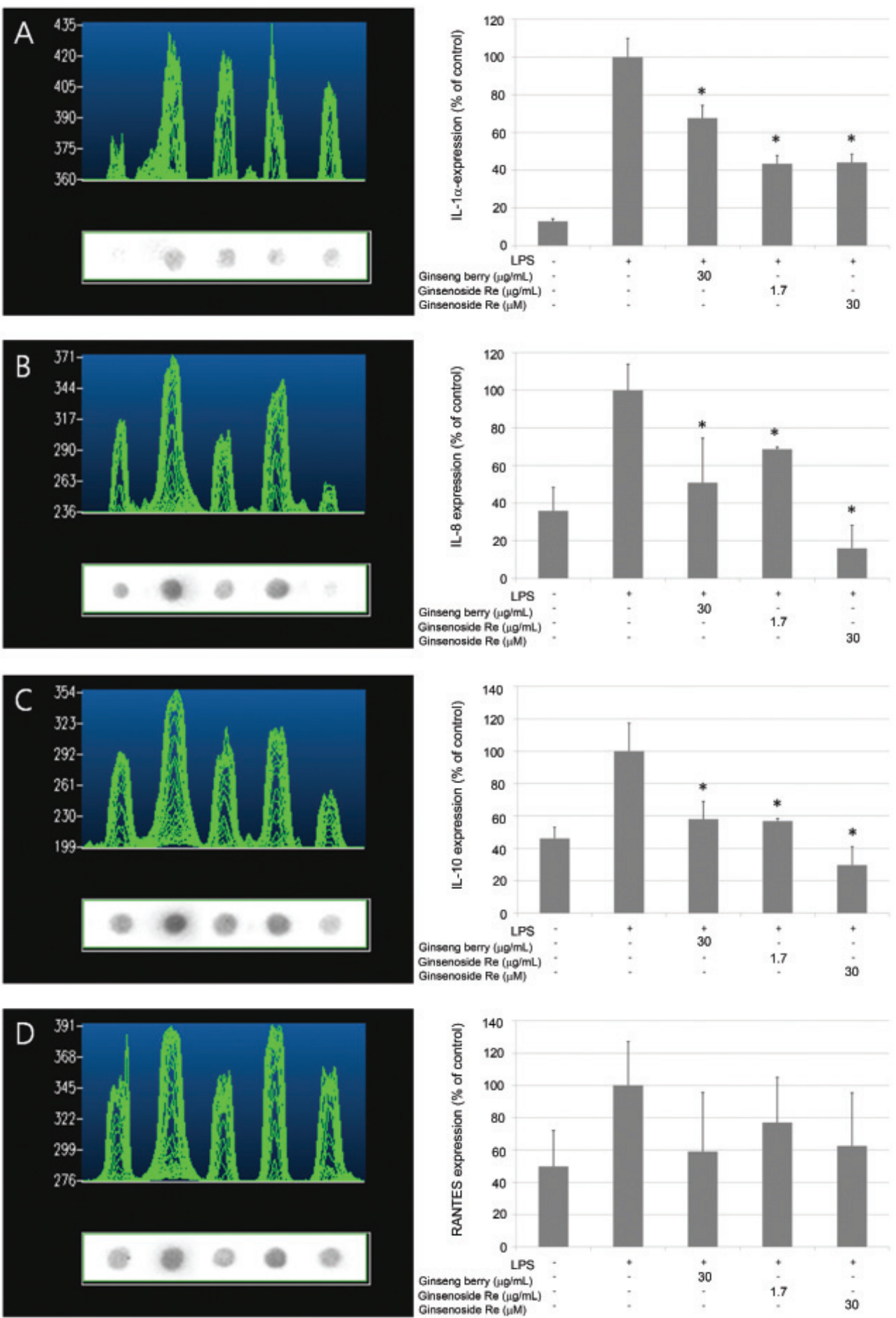

Fig. 4. (A-D) Cytokine array photographs and quantitatively analyzing graphs. A549 cells were incubated lipopolysaccharide (LPS) and/or each sample ( ${ }^{*} p<0.05$ vs. LPS treated control). RANTES, regulated and normal T cell expressed and secreted.

exhibiting $49.6 \pm 4.8 \%, 47.2 \pm 5.3 \%, 51.3 \pm 4.5 \%$, and $79.0 \pm 1.2 \%$, respectively $(p<0.05)$ (Fig. 3B).

The content of ginsenoside Re in crude extract was found out via HPLC analysis (5.9\%). The ginsenoside content in $30 \mu \mathrm{g}$ of crude extract is $1.7 \mu \mathrm{g}$, accordingly.
As the molecular weight of ginsenoside $\mathrm{Re}$ is 947.14 , the molar concentration of ginsenoside $\operatorname{Re}(1.7 \mu \mathrm{g} / \mathrm{mL}$, the content in $30 \mu \mathrm{g} / \mathrm{mL}$ of crude extract) is $1.8 \mu \mathrm{M}$. The effect of 1 and $3 \mu \mathrm{M}$ of ginsenoside Re could significantly reduce the histamine secretion. Therefore ginsenoside 
Re might be thought to be a main effective component of ginseng berry in the present histamine secreting experiment.

In cytokine assay experiments, the most effective dosages of ginseng berry and ginsenoside Re were determined to be $30 \mu \mathrm{g} / \mathrm{mL}$ and $30 \mu \mathrm{M}$, respectively. Because ginsenoside $\mathrm{Re}$ is a component of ginseng berry extract $(5.9 \%), 1.7 \mu \mathrm{g} / \mathrm{mL}$ ginsenoside Re treated group was also tested to find out the role of ginsenoside Re in total crude extract.

The IL-1 $\alpha$, IL-8, IL-10, and regulated and normal T cell expressed and secreted (RANTES) secretion were increased by LPS treatment (Fig. 4). Ginseng berry extract could reduce the IL-1 $\alpha$, IL-8, IL-10, and RANTES secretion induced by LPS treatment. Similarly, ginsenoside $\operatorname{Re}(1.7 \mu \mathrm{g} / \mathrm{mL}$, the amount in $30 \mu \mathrm{g}$ of ginseng berry extract) could reduce the IL-1 $\alpha$, IL- 8 , IL-10, and RANTES secretion. In the experiments of IL- 8 and IL10 , ginsenoside $\operatorname{Re}(30 \mu \mathrm{M})$ showed the effects in a dosedependent manner.

As results of the present study, ginsenoside Re was thought to be a main effective component of ginseng berry and the effects of ginsenoside Re were more powerful in higher dosages. The health promoting product having higher content of ginsenoside Re might be a health functional food.

\section{ACKNOWLEDGEMENTS}

This study was supported by the Technology Development Program of the Ministry of Agriculture and Forestry, Republic of Korea.

\section{REFERENCES}

1. Kitagawa I, Taniyama T, Shibuya H, Noda T, Yoshikawa M. Chemical studies on crude drug processing. V. On the constituents of ginseng radix rubra (2): comparison of the constituents of white ginseng and red ginseng prepared from the same Panax ginseng root. Yakugaku Zasshi 1987; 107:495-505.

2. Namba T. The encyclopedia of Wakan-Yaku with color pictures. Osaka: Hoikusha Publishing Co., 1980.

3. Park JD. Recent studies on the chemical constituents of Korean ginseng (Panax ginseng C. A. Meyer). Korean J Ginseng Sci 1996;20:389-415.

4. Sanada S, Kondo N, Shoji J, Tanaka O, Shibata S. Studies on the saponins of ginseng. I. Structures of ginsenosideRo,-Rb1,-Rb2,-Rc and-Rd. Chem Pharm Bull (Tokyo) 1974;22:421-428.
5. Shibata S, Tanaka O, Ando T, Sado M, Tsushima S, Ohsawa T. Chemical studies on oriental plant drugs. XIV. Protopanaxadiol, a genuine sapogenin of ginseng saponins. Chem Pharm Bull (Tokyo) 1966;14:595-600.

6. Tanaka O, Nagai M, Shibata S. Chemical studies on the oriental plant drugs. XVI. The stereochemistry of protopanaxadiol, a genuine sapogenin of ginseng. Chem Pharm Bull (Tokyo) 1966;14:1150-1156.

7. Mochizuki M, Yoo YC, Matsuzawa K, Sato K, Saiki I, Tono-oka S, Samukawa K, Azuma I. Inhibitory effect of tumor metastasis in mice by saponins, ginsenoside-Rb2, 20(R)- and 20(S)-ginsenoside-Rg3, of red ginseng. Biol Pharm Bull 1995;18:1197-1202.

8. Yokozawa T, Kobayashi T, Oura H, Kawashima Y. Studies on the mechanism of the hypoglycemic activity of ginsenoside-Rb2 in streptozotocin-diabetic rats. Chem Pharm Bull (Tokyo) 1985;33:869-872.

9. Takagi K, Saito H, Nabata H. Pharmacological studies of Panax ginseng root: estimation of pharmacological actions of Panax ginseng root. Jpn J Pharmacol 1972;22:245-249.

10. Jung IS, Cho YD. Effect of ginseng saponin fraction on absorption of cholesterol and serum lipid components. Korean J Ginseng Sci 1985;9:232-239.

11. Yoon SH, Joo CN. Study on the preventive effect of ginsenosides against hypercholesterolemia and its mechanism. Korean J Ginseng Sci 1993;17:1-12.

12. Kim YS, Kim YH, Noh JR, Cho ES, Park JH, Son HY. Protective effect of Korean red ginseng against aflatoxin B1-induced hepatotoxicity in rat. J Ginseng Res 2011;35:243-249.

13. Saito H, Yoshida Y, Takagi K. Effect of Panax ginseng root on exhaustive exercise in mice. Jpn J Pharmacol 1974;24:119-127.

14. Wang BX, Cui JC, Liu AJ, Wu SK. Studies on the anti-fatigue effect of the saponins of stems and leaves of Panax ginseng (SSLG). J Tradit Chin Med 1983;3:89-94.

15. Park MS, Cho EJ, Lee SK, Lee EJ, Lee DS, Lee KH, Jeon $\mathrm{BH}$. Korean red ginseng protects oxidative injury caused by lead poisoning. J Ginseng Res 2010;34:132-137.

16. Matsuda H, Samukawa K, Kubo M. Anti-inflammatory activity of ginsenoside Ro. Planta Med 1990;56:19-23.

17. Yokozawa T, Oura H. Facilitation of protein biosynthesis by ginsenoside-Rb2 administration in diabetic rats. J Nat Prod 1990;53:1514-1518.

18. Jie YH, Cammisuli S, Baggiolini M. Immunomodulatory effects of Panax ginseng C.A. Meyer in the mouse. Agents Actions 1984;15:386-391.

19. Lee CR, Whang WK, Shin CG, Lee HS, Han ST, Im BO, Ko SK. Comparison of ginsenoside composition and 
contents in fresh ginseng roots cultivated in Korea, Japan, and China at various ages. Korean J Food Sci Technol 2004;36:847-850.

20. Kim MW, Ko SR, Choi KJ, Kim SC. Distribution of saponin in various sections of Panax ginseng root and changes of its contents according to root age. Korean J Ginseng Sci 1987;11:10-16.

21. Jang JG, Lee KS, Kwon DW, Nam KY, Choi JH. Study on the changes of saponin contents in relation to root age of Panax ginseng. J Korean Soc Food Sci Nutr 1983;12:37-40.

22. Xie JT, Wang CZ, Ni M, Wu JA, Mehendale SR, Aung $\mathrm{HH}$, Foo A, Yuan CS. American ginseng berry juice intake reduces blood glucose and body weight in ob/ob mice. J Food Sci 2007;72:S590-S594.

23. Xie JT, Aung HH, Wu JA, Attel AS, Yuan CS. Effects of American ginseng berry extract on blood glucose levels in ob/ob mice. Am J Chin Med 2002;30:187-194.

24. Dey L, Zhang L, Yuan CS. Anti-diabetic and anti-obese effects of ginseng berry extract: comparison between intraperitoneal and oral administrations. Am J Chin Med 2002;30:645-647.

25. Wang W, Zhao Y, Rayburn ER, Hill DL, Wang H, Zhang R. In vitro anti-cancer activity and structure-activity relationships of natural products isolated from fruits of Panax ginseng. Cancer Chemother Pharmacol 2007;59:589-601.

26. Wang CZ, Zhang B, Song WX, Wang A, Ni M, Luo X, Aung HH, Xie JT, Tong R, He TC et al. Steamed American ginseng berry: ginsenoside analyses and anticancer activities. J Agric Food Chem 2006;54:9936-9942.

27. Xie JT, Shao ZH, Vanden Hoek TL, Chang WT, Li J, Mehendale S, Wang CZ, Hsu CW, Becker LB, Yin JJ et al. Antioxidant effects of ginsenoside Re in cardiomyocytes. Eur J Pharmacol 2006;532:201-207.

28. Shao ZH, Xie JT, Vanden Hoek TL, Mehendale S, Aung H, Li CQ, Qin Y, Schumacker PT, Becker LB, Yuan CS. Antioxidant effects of American ginseng berry extract in cardiomyocytes exposed to acute oxidant stress. Biochim Biophys Acta 2004;1670:165-171.

29. Mehendale SR, Wang CZ, Shao ZH, Li CQ, Xie JT, Aung HH, Yuan CS. Chronic pretreatment with American ginseng berry and its polyphenolic constituents attenuate oxidant stress in cardiomyocytes. Eur J Pharmacol 2006;553:209-214.

30. Huo YS. Anti-senility action of saponin in Panax ginseng fruit in 327 cases. Zhong Xi Yi Jie He Za Zhi 1984;4:593596,578 .

31. Zhang SC, Jiang XL. The anti-stress effect of saponins extracted from Panax ginseng fruit and the hypophysealadrenal system. Yao Xue Xue Bao 1981;16:860-863. 